DEPÓSITO LEGAL ZU2020000153

Esta publicación científica en formato digital

es continuidad de la revista impresa

ISSN 0041-8811

E-ISSN 2665-0428

Revista

de la

Universidad

del Tunlia

Fundada en 1947

por el Dr. Jesús Emrique Lossada

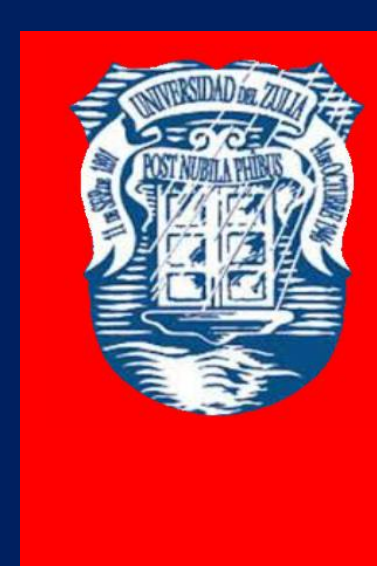

Ciencias

Sociales

y Arte

Aกัต 11 No 31

Septiembre - Diciembre 2021

Tercera ípoca

Maracailbo-Venezuela 


\title{
Russia-Belarus integration interaction in the context of the development of the Eurasian Economic Union
}

\author{
Vladimir M. Kozmenko * \\ Saken Zh. Toktamysov ** \\ Erlan D. Shamishev ***
}

\begin{abstract}
The article is devoted to the analysis of Russia-Belarus integration interaction. The authors consider the main areas of cooperation between these two countries and analyze the prospects for the development of bilateral relations. The importance of military and militarytechnical cooperation between Russia and Belarus is noted in the context of ensuring national security and joint counteraction against current challenges and threats. There is the important role of the Union State as a universal model of integration in the post-Soviet states. The authors adhere to a comprehen sive methodology in the study of integration issues, which allowed us to significantly expand and deepen the analysis of the most significant and basic aspects of integration development in the context of the construction of the Union State, and the multidimensionality of the object of study determined the multiplicity of approaches to its study. The research methodology is based on a systematic approach, using the principle of historicism to analyze the above issues. The object of the study is the integration processes in the post-Soviet space, and the subject of the study is the system of political relations between Russia and Belarus in the context of the construction of a single Union State. The organizational and functional complexity of the object and subject of the study predetermined the pluralism of the methodological approaches used. The conceptual apparatus of the study is predetermined by the chosen methodological guidelines and is closely linked to the specific material being analyzed.
\end{abstract}

KEY WORDS: Belarus, Collective Security Treaty Organization (CSTO), economy, Eurasian Economic Union (EAEU), globalization, national interests, post-Soviet states, protective measures, regional integration, Russia, sanctions, strategic ally, Union State.

* Friendship University of Russia (RUDN University), 117198 Miklukho-Maklaya Street 6, Moscow, Russia, ORCID: http:// 0000-0003-0702-9490,v.kozmenko@gmail.com

** Friendship University of Russia (RUDN University), 117198 Miklukho-Maklaya Street 6, Moscow, Russia, ORCID: http:// 0000-0003-4284-9638, stoktamysov@gmail.com

*** Diplomatic Academy of the Ministry of Foreign Affairs of the Russian Federation, 119021 Ostozhenka Street 53/2 building 1, Moscow, Russia; Researcher of the International scientific complex "Astana”, Republic of Kazakhstan, E.Shamishev@akorda.kz 


\section{Interacción de la integración Rusia-Bielorrusia en el contexto del desarrollo de la Unión Económica Euroasiática}

RESUMEN El presente artículo está dedicado al análisis de la interacción en la integración entre Rusia y Bielorrusia. Los autores estudiaron las principales áreas de cooperación entre estos dos países y analizaron las perspectivas para el desarrollo de las relaciones bilaterales. La importancia de la cooperación militar y militar-técnica entre Rusia y Bielorrusia fue analizada en el contexto de garantizar la seguridad nacional y la lucha conjunta contra los desafíos y amenazas actuales. En el documento se valora el importante papel desempeñado por el Estado de la Unión como modelo universal de integración en los estados postsoviéticos. Los autores se adhieren a una metodología integral en el estudio de los problemas de integración, lo que permitió expandir y profundizar significativamente el análisis de los aspectos más significativos y básicos del desarrollo de la integración en el contexto de la construcción del Estado de la Unión, y la multidimensionalidad del objeto de estudio determinó su multiplicidad de enfoques. La metodología de investigación se basa en un enfoque sistemático, utilizando el principio del historicismo para analizar los problemas anteriores. El objeto del estudio son los procesos de integración en el espacio postsoviético, y el tema del estudio es el sistema de relaciones políticas entre Rusia y Bielorrusia en el contexto de la construcción de un único Estado de la Unión. La complejidad organizacional y funcional del objeto y sujeto del estudio predeterminó el pluralismo de los enfoques metodológicos utilizados. El sistema conceptual del estudio está predeterminado por las pautas metodológicas elegidas y está estrechamente relacionado con el material específico que se analiza.

PALABRAS CLAVE: Bielorrusia, Organización del Tratado de Seguridad Colectiva (OTSC), economía, Unión Económica Euroasiática (EAEU), globalización, intereses nacionales, estados postsoviéticos, medidas de protección, integración regional, Rusia, sanciones, aliado estratégico, Estado de la Unión.

Introduction

At the modern stage of globalization and strengthening the interdependence of different states, the role of integration structures is growing in the context of developing perspective areas of multilateral cooperation and increasing the efficiency of existing mechanisms for implementing the decisions (Grebenichenko \& Toktamysov, 2011). An important factor that will determine the development of EAEU is the deepening of economic integration between its two members: Russia and Belarus. It will have a direct and indirect 
REVISTA DE LA UNIVERSIDAD DEL ZULIA. $3^{a}$ época. Año 11 N³1, 2020

Vladimir M. Kozmenko et al/// Russia-Belarus integration interaction ...195-222

DOI: http://dx.doi.org/10.46925//rdluz.31.14

impact on the national interests of the other member states of the Union (Shamishev \& Toktamysov, 2019).

Trade and economic cooperation between Russia and Belarus has traditionally developed since the established cooperation from the Soviet period. The formation of EAEU did not have a significant impact on their development. The most important format of RussiaBelarus interaction remains the Union State as a universal model of integration in the postSoviet states.

The purpose of the study is to identify and summarize the historical experience of the formation and development of cooperation between the Russian Federation and the Republic of Belarus in the context of integration development in the post-Soviet space.

\section{Literature Review}

An intensive study of these processes began in Europe and in Soviet Union almost simultaneously and independently from each other in the early 1950s by a number of Russian and foreign socio-political schools. In this regard, the concept of "political unification" by A. Etzioni, the analysis of integration unification as a political system by P. Soldatos, the political and social concept of "continental integration" by A. Marshall, the concept of "political networks" by J. Peterson, structural "integration theory" by J. Galtung, as well as the theory of multilevel management based on the intergovernmental approach of $\mathrm{W}$. Wallace and E. Moravchik (Moravcsik, 1995).

In recent years, there has been an increase in research interest in the political and economic aspects of integration in the post-Soviet states (Shtol, 2012; Egorov, Savina, 2012; Irkhin, 2014; Libman \& Kheifets, 2011; Pankov, 2007). Representatives of the Russian school mainly focus on the processes of regional and economic integration in their studies.

There are theoretical approaches of Russian authors to integration studies in the analysis of the formation processes of the Commonwealth of Independent States (CIS), EAEC (Rapota, 2005), Eurasian Customs Union (EACU) and the Free Trade Area in the works of Russian experts (Evzerov, 2002; Vinokurov et al, 2009; Kornilovich, 2007; Lokosov, 2011; Delyagin, 2005).

There are problems of relations between Russia and Belarus in the framework of the construction of the Union State and the problems of institutionalization of the interaction 
REVISTA DE LA UNIVERSIDAD DEL ZULIA. $3^{a}$ época. Año 11 N³1, 2020

Vladimir M. Kozmenko et al/// Russia-Belarus integration interaction ...195-222

DOI: http://dx.doi.org/10.46925//rdluz.31.14

between these two countries in a number of studies (Kachalov, 2003; Godin, 2001; Avakyan, 2001; Vishnyakov, 2002; Mikhaleva, 2002; Pastukhova, 2000; Kabalevich, 2002; Dmitriev \& Khurs, 2002; Koktysh, 2004; Konobeev, 2003; Timmerman, 2006; Shakleina 2000; Shakleina 2010).

In general, in the special scientific literature devoted to the problem of the construction and functioning of the Union State of Russia and Belarus in the context of integration processes in the post-Soviet states, there are three main conceptual directions:

- $\quad$ integration development in the political sphere, supported by a number of researchers (Arbatov, 2004a; Arbatov, 2004b; Ilyin, 2004; Suzdaltsev, 2009; Tatarintsev, 2011);

- integration development in the economic sphere, actively developed in the works of Glazyev S.Yu. (2001; 2007), Afonina V.N. (2007), Ushkalova D.I. (2008), Fedosov B.N. (2006);

- integration development in the sociocultural sphere (Drobizheva, 2003; Lublinsky, 2005; Tkachev, 2006).

Separately, it is necessary to note the contribution to the study of both the security issues of the Union of Russia and Belarus, and all integration processes in the CIS by the "Center for the Study of the CIS", which was created at the Peoples' Friendship University of Russia on the initiative of the honored scientist of the Russian Federation and academician of the Russian Academy of Natural Sciences, professor V. M. Kozmenko. These are the fundamental works of Vladimir Matveevich Kozmenko himself (Kozmenko, 2001; Kozmenko, 2009; Kozmenko, 2012a; Kozmenko, 2012b; Kozmenko \& Sagindikov, 2014), as well as his associates and students: S.F. Grebichenko, V.P. Davydov, A.M. Sarazhanov, A.V. Imankulov, R.E. Sagindikov, I.A. Akbergenov, S.Zh. Toktamysov (Sarazhanov, 2002; Akbergenov et al, 2005; Grebenichenko \& Davydov, 2005a; Grebenichenko \& Davydov, 2005b; Imankulov, 2005; Grebenichenko \& Davydov, 2007; Grebenichenko \& Davydov, 2008; Akbergenov, 2009; Davydov \& Grebenichenko, 2009a; Davydov \& Grebenichenko, 2009b; Davydov \& Grebenichenko, 2009c; Grebenichenko, 2009; Grebenichenko \& Toktamysov, 2010; Grebenichenko, 2011; Grebenichenko \& Toktamysov, 2011; Grebenichenko, 2012a; Grebenichenko, 2012b; Grebenichenko \& Toktamysov 2013a; Grebenichenko \& Toktamysov, 2013b; Grebenichenko \& Sagindikov, 2014). 
REVISTA DE LA UNIVERSIDAD DEL ZULIA. 3época. Año 11 N 31, 2020

Vladimir M. Kozmenko et al/// Russia-Belarus integration interaction ...195-222

DOI: http://dx.doi.org/10.46925//rdluz.31.14

Despite a lot of official documents: laws, decrees, directives, decisions and other regulatory legal acts, as well as other information sources on political, economic, legal and social problems of relations between Russia and Belarus, there is a clear lack of research, primarily in the system of institutionalization of integration processes, both at the national and supranational levels.

\section{Methodology}

The paper comprehensively examines the problems of the integration development of the post-Soviet states using the example of building a single Union State of Russia and Belarus. New mechanisms for the integration development of these two countries in the framework of the Union State are proposed, and methods for intensifying the integration relations of Russia and Belarus are also considered. The authors showed the main characteristics of the Union State, identified the main goals and objectives and the most significant problematic aspects.

In the work, general scientific methods of historical research were used: analysis, synthesis, generalization and other specific problem methods, i.e. methods that are used in the study of certain specific historical phenomena in the light of various research tasks. To a greater extent, the scientific publication used an interdisciplinary, historical-systemic method aimed at studying objects and phenomena of the past as integral historical systems: analysis of their structure and functions, internal and external relations (morphology), as well as dynamic changes (genesis) based on historical, political, economic, legal and military principles of research. The approaches and methods used in the work made it possible to study aspects of the integration interaction of the Russian Federation and the Republic of Belarus in the dynamics of their development and the variety of domestic and foreign policy decisions.

The authors adhere to a comprehensive methodology in the study of these problems, which allowed to significantly expand and deepen the analysis of the most significant and basic aspects of integration development in the context of the construction of the Union State. The study used prognostic, statistical and situational analysis, method of expert assessments and elements of a systemic, structural-functional, comparative, and institutional analysis. The authors used principles that allow combining the capabilities of logical and historical methods and quantitative and qualitative analysis. 
REVISTA DE LA UNIVERSIDAD DEL ZULIA. $3^{a}$ época. Año 11 N³1, 2020

Vladimir M. Kozmenko et al/// Russia-Belarus integration interaction ...195-222

DOI: http://dx.doi.org/10.46925//rdluz.31.14

The source of the research base is constituted by regulatory legal acts: Agreements, agreements, resolutions, directives and other program documents of the Russian Federation, the Republic of Belarus, the CIS, as well as information contained in official documents, scientific, reference and periodical literature on the topic under study. A large layer of information is provided by traditional periodicals, which are actively used by party representatives, statesmen and other persons to promote their views and ideas. This type of source, being a special indicator of the reflection of diverse processes in the public consciousness, reveals the forms, content, results of various aspects of relations between Russia and Belarus in the period under study.

The indicated groups of sources provide sufficient factual material to solve the problems posed in the study. These sources are very diverse in species, origin and time of creation. Their analysis and synthesis made it possible to obtain the information necessary for the study.

\section{Theoretical Basis}

Russia-Belarus cooperation in the format of the Union State is different and covers a lot of areas: trade and economic, investment, energy cooperation, budget, formation of a unified transport system, functioning of the regional grouping of troops on the territory of Russia and Belarus. An important element of Russia-Belarus cooperation is the strengthening of inter-regional cooperation and growing institutionalization of a system of horizontallyoriented ties (Forum of Russian and Belarusian Regions) (Novikov, 2019).

Since the mid-2010s the Russian approach is becoming more pragmatic, which makes significant changes to the usual patterns of Russia-Belarus economic interaction.

Russian government realized that the previous economic paternalism in the state policy of Russia in relations with partners in the CIS was ineffective, and in the conditions of high costs in the confrontation with the West, it was costly and unjustified. As a result, Russian political and business community had the opinion that Moscow should stop subsidizing the Belarusian economy for free. According to Russian experts, the budget losses of Russia in 2011-2016 amounted to more than 26 billion dollars because of the consent to supply Belarus with duty free from 18 to 23 million tons of oil annually. According to expert 
REVISTA DE LA UNIVERSIDAD DEL ZULIA. $3^{a}$ época. Año 11 N³1, 2020

Vladimir M. Kozmenko et al/// Russia-Belarus integration interaction ...195-222

DOI: http://dx.doi.org/10.46925//rdluz.31.14

estimates, Belarus over the past 10 years has received about 60 billion dollars from Russia in the form of various subsidies and discounts.

Another factor that prompted Moscow to take more decisive actions was the dual policy of Minsk aimed at rapprochement with China, European Union (EU) (Eastern Partnership neighborhood program) and the United States of America (USA), which is due to the internal political needs of the Belarusian leadership. In the relations between EU and Belarus, there is the situation where EU leadership, using the economic difficulties of this country, is stepping up efforts to encourage Minsk to make concessions in domestic and foreign policy in exchange for facilitating access to the European market and simplifying customs procedures (Chufrin, 2020).

The course towards normalizing relations between Belarus and the West is primarily associated with the role that Belarus plays for regional security after the start of the Ukrainian crisis. As for China, Belarus sees it as an alternative source of investment, loans and technology. But China, unlike the West and Russia, provides loans without any political conditions. The lack of a common border and geographical remoteness also eradicates fears of "Chinese Economic Expansion". In turn, China sees Belarus as an important element in promoting the "Belt and Road Initiative" to Europe. Beijing is also interested in the supply of natural organic products and potash fertilizers from Belarus. Belarus-China joint venture for the production of potash fertilizers, which are exported to China and countries of Eastern Europe, has already been created in Belarus. The most successful projects were the following: Belarus-China industrial park "Great Stone", "High Technology Park" (HTP) for IT companies, special economic zone in Orsha district. At the same time, HTP has become a successful example of public-private partnerships focused on the export of high-tech products. More than 450 companies with 45700 people are in HTP. Almost a half (49\%) of the software created at HTP is delivered to Europe, $44 \%$ to the USA and Canada and 4\% to Russia and CIS countries (Dmitriev \& Novikov, 2019).

Russia has always regarded Belarus as a special and strategic ally. The countries closely interact within the Union State, CSTO and EAEU. They share a common point of view in the field of defense and security. However, over the past 5 years, the situation in EAEU and the military-political situation in the region of Eastern Europe and the Baltic countries have changed dramatically. Moscow seeks to maintain its influence on Minsk in 
REVISTA DE LA UNIVERSIDAD DEL ZULIA. 3época. Año 11 N 31, 2020

Vladimir M. Kozmenko et al/// Russia-Belarus integration interaction ...195-222

DOI: http://dx.doi.org/10.46925//rdluz.31.14

the context of a geopolitical confrontation with the West, building up NATO offensive forces near the northwestern borders of EAEU.

For the Russian military and politicians, Poland's plans to militarize the eastern borders are the reasons to worry. Russia-Poland relations become worse due to different interpretations of the outbreak of Second World War and the conflict in southeastern Ukraine, Warsaw is increasing its defense spending and is making efforts and additional NATO units. In particular, 4 Polish divisions are deployed near the Belarusian border; in 2022, USA missile defense system Aegis Ashore will take up combat duty on the border with the Kaliningrad region of Russia. In addition, Warsaw insists on deploying an American military base on Polish territory and is ready to allocate about 2 billion dollars for this. In the event of "loss of Belarus", Russian defense space will be significantly reduced (from the Russia-Belarus border to Moscow there are a little more than $400 \mathrm{~km}$ ) (Bogaturov et al, 2002).

These fears of Moscow are successfully used by representatives of the Belarusian elite. The military and military-technical cooperation between these two countries is intensifying. As a part of the cooperation plan of the military departments of Russia and Belarus, in 2019, the Union Shield-2019 combined-arms maneuvers were held, as well as counter-terrorism measures were developed in the event of a hypothetical enemy invasion.

At the same time, Belarus refuses Russia to deploy a Russian military base on its territory. According to president A. Lukashenko, there is no need for a Russian military base, "Belarusian army is able to protect its country from any aggression" (in Belarus there are 2 Russian radars near Hantsavichy and a long-distance communications point with submarines of the Russian Navy near Vileyka).

It is important to note that after the Ukrainian crisis, Minsk increased military spending to 1 billion dollars per year. Territorial defense troops were created in the Belarusian army, which should begin partisan and sabotage actions against the aggressor. Moreover, the maintenance of them is less burdensome for the budget than the regular army.

Nowadays, the Belarusian army (62000 people) is considered the most combat-ready and prepared in the post-Soviet states after the Russian one. Belarus has a developed defense industry and creates its own weapons models: 2T Stalker (tank), Stilet air defense system 
REVISTA DE LA UNIVERSIDAD DEL ZULIA. 3época. Año $11 N^{\circ}$ 31, 2020

Vladimir M. Kozmenko et al/// Russia-Belarus integration interaction ...195-222

DOI: http://dx.doi.org/10.46925//rdluz.31.14

and Skif and Shershen anti-tank missile systems. Together with China, Polonaise multiple launch rocket system is being manufactured.

Military and military-technical cooperation plays an important role in Russia-Belarus relations. Belarus inherited a significant part of the Soviet military-industrial complex. Belarusian defense enterprises specialized in the manufacturing of high-tech products, including navigation systems and aircraft equipment, satellite equipment, space communications devices, automation systems and software, heavy trucks and chassis for strategic and operational-tactical mobile missile systems (Zayko et al, 1999). In the Soviet period, the Belarusian economy was quite militarized, although Belarusian enterprises produced 1-3\% of the total volume of Soviet defense products. According to some expert estimates, defense production amounted to at least 70\% of Belarusian industry (Zayko et al, 1999). In general, almost $70 \%$ of the military specialists of the former Soviet army and about $75 \%$ of the military potential of the USSR were concentrated in Russia and Belarus (Podlesny, 1995). The total number of armed forces of Belarus at the time of the collapse of the USSR could be 160000 people (Mihalisko, 1992). By the early 1990s Belarus possessed the 6th world nuclear arsenal, about 10\% of the republic's territory was occupied by military bases (Mihalisko, 1996).

The Belarusian military-industrial complex is characterized by a high level of integration with the Russian military-industrial complex: Belarusian industry is not able to meet the national needs of the armed forces without appropriate cooperation with Russia, it does not have closed production cycles and cannot produce finished goods. According to a lot of experts, Belarus developed national defense production as a part of the Russian defense industry, Belarusian military exports were carried out by Belarusian enterprises as subcontractors of Russian defense enterprises (Legwold \& Wallander, 2004).

Cooperation in the military-technical field is currently developing dynamically. Delivery, repair and modernization of anti-aircraft missile weapons, communications and electronic warfare, small arms and artillery weapons, ammunition and aviation equipment is being carried out. Meetings of the intergovernmental commission on military-technical cooperation are held annually (Shishkov, 2001).

Important factors determining the intensification of military-technical cooperation between Russia and Belarus are that these states participate in joint integration projects and 
REVISTA DE LA UNIVERSIDAD DEL ZULIA. $3^{a}$ época. Año 11 N³1, 2020

Vladimir M. Kozmenko et al/// Russia-Belarus integration interaction ...195-222

DOI: http://dx.doi.org/10.46925//rdluz.31.14

have a common customs and defense space. Similar approaches to the process of formation of the military industry have also developed here; there is a significant affinity in the national arms systems and military equipment. A significant part of military equipment, the production of which is carried out on the territory of Russia, is equipped with components of Belarusian production. In particular, T-90S, T-72S, T-80U tanks, airborne and infantry fighting vehicles, artillery systems, repair and recovery vehicles, anti-tank missile and antiaircraft systems, melee weapons, and small arms were equipped with Belarusian spare parts (Sobin, 2012). Russia-Belarus cooperation in the field of defense and security, anti-terrorism activities and the fight against crime is being strengthened. Measures are being taken to restore cooperative ties between defense industry enterprises. The joint regional grouping of troops is functioning effectively.

Joint military scientific activity is carried out in the following main areas:

- $\quad$ organization of joint scientific research and development of a draft concept for a program of fundamental and exploratory research in the field of ensuring the military security of the Union State;

- $\quad$ joint military historical research and preparation for the publication of books dedicated to the 25th anniversary of the withdrawal of Soviet troops from Afghanistan, the 70th anniversary of the liberation of Belarus from Nazi invaders, the 100th anniversary of the outbreak of the First World War, manuscript of the joint work "The Peoples of Russia and Belarus during the Napoleonic invasion"; training of scientific and pedagogical personnel in military educational institutions of Russia.

At the conceptual level, military-political cooperation between Russia and Belarus is carried out within the framework of the contract on the creation of the Union State and CSTO. The legal framework of military cooperation between Belarus and Russia is represented by more than 30 international contracts. The basis of such cooperation are several basic documents: contract between Belarus and Russia on military cooperation; agreement between them on the joint provision of regional security in the military sphere; security concept of the Union of Belarus and Russia; concept of joint defense policy; military doctrine of the Union State. The defining document is the military doctrine of the Union State, which is defensive in nature and aimed at ensuring the territorial integrity and 
REVISTA DE LA UNIVERSIDAD DEL ZULIA. $3^{a}$ época. Año 11 N³1, 2020

Vladimir M. Kozmenko et al/// Russia-Belarus integration interaction ...195-222

DOI: http://dx.doi.org/10.46925//rdluz.31.14

sovereignty of these two countries, maintaining the strategic stability of the Union State, creating conditions for a lasting and just world (Tsyganok, 2009).

An important element that determines the military-political integration of Russia and Belarus is the change in the geopolitical situation that occurred after the collapse of the USSR. During the creation of the Union State, an important task of Russian diplomacy was the struggle against NATO eastward expansion. Subsequently, the Russian policy regarding NATO expansion will undergo a certain transformation, but the Russian official position on NATO has remained negative. The development of the integration interaction of Russia with Belarus in the military sphere largely acts as a response in the framework of the strategy to counter NATO expansion (Grebenichenko \& Toktamysov, 2013c).

The most important factor determining the need for military-technical cooperation between Russia and Belarus is the location on the territory of Belarus of the most important military infrastructure facilities: radar station near Baranavichy (early-warning radar: Hantsavichy Radar Station of Volga-type radar). It is designed to detect in flight ballistic missiles and space objects at a distance of up to $5000 \mathrm{~km}$, as well as to track, identify and measure the coordinates of targets in the western direction, followed by the issuance of information about the state of airspace at the early-warning radar system. Another Russian military facility in Belarus is the submarine command post in Vileyka. The station there is designed to relay signals to Russian ships and submarines located in the Central and North Atlantic (Olcott, 1996).

One of the important elements of military cooperation within the framework of the Union State is the provision of the functioning of a regional group of forces. Later, this group became the foundation of CSTO.

The basis for the creation of the regional group of forces of Belarus and Russia was the Collective Security Concept of CSTO, adopted under the CST agreement, approved by the Decision of the Collective Security Council on February 10, 1995. In this Concept, coalition forces are considered as one of the elements of the forces and means of the collective security system of the participating states. With the aim of further integration of Belarus and Russia in the military sphere, the general principles of military construction and the use of elements of the military infrastructure of these two states were approved by a decision of the supreme council of the Community of Belarus and Russia of April 2, 1997. There, the development and 
REVISTA DE LA UNIVERSIDAD DEL ZULIA. $3^{a}$ época. Año 11 N³1, 2020

Vladimir M. Kozmenko et al/// Russia-Belarus integration interaction ...195-222

DOI: http://dx.doi.org/10.46925//rdluz.31.14

improvement of the organizational and staffing structure and composition of the regional group of forces is determined by one of the main directions of coordination of military construction of the armed forces, the use of elements of the military infrastructure of both states (Luzyanin, 2007).

The next step in the creation of the regional group of forces was the approval, by decision of the Supreme Council of the Union of Belarus and Russia of January 22, 1998, of the Concept of the joint defense policy of Belarus and Russia, which defines the composition, basics of planning, application, management and comprehensive support of the regional group of forces. In development of the Concept of the joint defense policy of Belarus and Russia on May 5, 1998, an Agreement between Belarus and Russia on the joint provision of regional security in the military sphere was ratified, which discloses the concepts of a region, a regional group of forces, the procedure for planning activities to ensure its functioning, the basis for organizing operational equipment territory in the region. Later, a number of other documents were approved governing various aspects of the functioning of the regional group of forces (Alpysbaeva et al, 2018).

The defining document is the military doctrine of the Union State, which is defensive in nature and aimed at ensuring the territorial integrity and sovereignty of both countries, maintaining the strategic stability of the Union State, creating conditions for a lasting and just world (Tsyganok, 2009).

Since 2012, the mechanism for implementing the contract between Belarus and Russia on the development of military-technical cooperation of December 10, 2009, has been launched. Deliveries of military products, works and services in the interests of law enforcement agencies are carried out according to a simplified scheme and at domestic prices (Golovchenko, 2013).

According to official information, the following components were included in the composition of the regional group of forces: Armed Forces of Belarus, the 20th Army of the Western Military District of the Armed Forces of Russia with formations, military units reinforcing central and district subordination. The functioning of the regional grouping of troops in peacetime is carried out by the practical implementation of the annual plan of joint measures to ensure its functioning. 
REVISTA DE LA UNIVERSIDAD DEL ZULIA. $3^{a}$ época. Año 11 N³1, 2020

Vladimir M. Kozmenko et al/// Russia-Belarus integration interaction ...195-222

DOI: http://dx.doi.org/10.46925//rdluz.31.14

The creation of the regional group of forces laid the foundation for the active development of integration processes in the military sphere of CSTO and CIS countries. In particular, a joint grouping of troops of Armenia and Russia in the Caucasus region was created. As a part of the bilateral military cooperation between Russia and Belarus, largescale military exercises are held to emphasize the combat readiness of the aforementioned military group. Belarusian and Russian units, formations, military units, military command and control bodies regularly take part in joint exercises and trainings in the territories of these two states. In 2013, the West-2013 joint strategic exercise of the armed forces of Belarus and Russia took place in Belarus.

Another important area of bilateral cooperation is the creation of a unified regional air defense system. On February 3, 2009, in Moscow, presidents of Belarus and Russia at a meeting of the Supreme State Council of the Union State signed the "Agreement between Belarus and Russia on joint protection of the Union's external border in the airspace and the creation of the Unified Regional Air Defense System of Belarus". The signing was preceded by active work in the field of improving the regulatory and legal framework for ensuring safety in the airspace in the Eastern European region of collective security. An important prerequisite for its development was the growing threat of terrorism, which required a revision of views on ensuring national security, as well as pooling efforts to counter this phenomenon. The conceptual basis of this cooperation was agreements, protocols, and a list of practical activities of the military departments of these two countries on the formation of the Unified Regional Air Defense System (URADS). In the 2000s technical refinement of the above documents was carried out, bringing them in line with the evolving military-political situation, achievements in the development of modern weapons and military equipment, and the focus on the economic development of these two countries. From that moment, detailed development of the combat personnel of the URADS, mechanism of functioning, issues of support, interaction and management and process of domestic approval of the draft agreement began.

The main objective of the URADS is the creation of a single grouping of forces and assets of Belarus and Russia in order to jointly protect the air borders of the Union State. URADS is headed by a commander who is appointed to this post by the Presidents of Russia and Belarus on the proposal of the defense ministers of these two countries. The composition 
REVISTA DE LA UNIVERSIDAD DEL ZULIA. $3^{a}$ época. Año 11 N³1, 2020

Vladimir M. Kozmenko et al/// Russia-Belarus integration interaction ...195-222

DOI: http://dx.doi.org/10.46925//rdluz.31.14

of the URADS includes: air force and defense of Belarus, air defense forces and means of two associations of the air force, as well as a part of the forces and means of the Baltic Fleet of Russia. The combat personnel of the URADS included aviation units, a group of anti-aircraft missile forces, units and subunits of radio engineering forces. Among the tasks solved by the URADS there are the following:

- $\quad$ guarding and protecting the external borders of the Union State;

- monitoring compliance with airspace use regulations;

- $\quad$ implementation of radar control;

- $\quad$ interaction with the troops that are part of the united URADS of the CIS member states.

As a part of the implementation of the provisions of the agreement, joint training of specialists is provided. The signing and implementation of it and the creation of URADS can significantly reduce the level of modern threats against the subjects of the Union State, increase security and the ability to counter modern world terrorism, and ensure the inviolability of state borders in the airspace.

Thus, military and military-political cooperation is considered by the Russian and Belarusian political elites to be the most important area of bilateral interaction within the Union State. The main reasons for such cooperation are not military, but economic aspects: strong integration and interdependence of the defense industry of these two states, important role of the military-technological potential in the economies of Russia and Belarus, special role of the military-industrial complex as a high-tech sector of the Russian economy, with a view to developing which is necessary to maintain and develop close cooperative ties with partners in the CIS. In the context of the functioning of the military-political unit of NATO, close military cooperation with Belarus is considered by the Russian elite as a tool to strengthen Russia's national security on the western borders, increasing the defense capabilities of these two states through the formation of a single armed forces and defense system of the Union State.

Due to the growth of military-political threats and the accelerated militarization of NATO in the region, Minsk is trying to strengthen its own economic security by continuing to obtain economic preferences and maintaining the previous model of cooperation within the Union State and EAEU: loyalty in exchange for the supply of hydrocarbons at preferential 
REVISTA DE LA UNIVERSIDAD DEL ZULIA. $3^{a}$ época. Año 11 N³1, 2020

Vladimir M. Kozmenko et al/// Russia-Belarus integration interaction ...195-222

DOI: http://dx.doi.org/10.46925//rdluz.31.14

prices, as well as the opening of the Russian market for Belarusian goods. Now, the level of integration between the economies of Belarus and Russia has reached a fairly high level.

According to official figures, Belarus ranks first in terms of trade between Russia and the CIS countries. Half of the Belarusian export products are supplied to the Russian market. According to preliminary data, in 2019, supplies of Belarusian meat and meat products to Russia amounted to about 3.2 million tons (11\% higher than in 2018) and milk and dairy products to 3.71 million tons (2.6\% higher than in 2018).

According to the estimates of the Center for Integration Studies of the Eurasian Development Bank, Belarus is the most integrated member of EAEU. More than half of their foreign trade turnovers have the countries of the Union. To a large extent, this means Belarus's close integration with the Russian economy, since Russia accounts for $93.2 \%$ of Belarusian exports to EAEU (5.6\% for Kazakhstan), as well as 99.4\% of its imports. In general, the share of Russia is almost $40 \%$ of Belarus' exports. Deliveries to other countries also depend on Russia. Thus, receiving Russian oil (29.1\% of the import of goods in 2018), Belarus processes it and exports oil products to third-country markets (25.5\% of all exports in 2018). In addition, Russia is the main investor and creditor for Belarus. Relations at the corporate level, especially in the basic sectors of the Belarusian economy, are becoming increasingly close. In 2018,38.3\% of the total foreign direct investment in the economy of Belarus came from Russia and over 37\% of the external borrowing of Belarus came from the government and banks of Russia. Other leading sources of foreign investment were the United Kingdom (25.7\%) and Cyprus (7.8\%). According to some estimates, investments from these countries are also of Russian origin, so Russia accounts over $70 \%$ of foreign direct investment in Belarus.

An important stage in Russia-Belarus cooperation is the approval by the prime ministers of these two countries in September, 2019 of the program of actions of Belarus and Russia on the implementation of the provisions of the contract establishing the Union State.

The program provides for partial economic integration of these two countries, including the adoption of a single Tax Code. Initially, it was assumed that the roadmaps for the unification of economies would be prepared, and the start of work in a unified regime should start on January 1, 2020. From the same period, a common customs and energy policy of these two countries, common principles of banking and financial supervision, mutual 
REVISTA DE LA UNIVERSIDAD DEL ZULIA. $3^{a}$ época. Año 11 N³1, 2020

Vladimir M. Kozmenko et al/// Russia-Belarus integration interaction ...195-222

DOI: http://dx.doi.org/10.46925//rdluz.31.14

access to public procurements, a unified system of property accounting and unification of economic legislation will begin to operate. Since January 1, 2022, two states intend to pursue a coordinated policy in the field of labor and social protection of the population. In the case of the full implementation of these areas, according to economists, the degree of integration in the Union State of Russia and Belarus will become higher than in the EU.

The program consists of 31 roadmaps, which provide for the approximation, unification and harmonization of legislation in the main areas. At the same time, issues of public administration, judicial and law enforcement spheres, defense, security, education, science and health are not addressed.

According to media reports, the program provides for the following measures:

- mutual cancellation of roaming from June 1, 2020;

- $\quad$ adoption of a single Tax Code by April 1, 2021;

- $\quad$ agreed social policy with similar guarantees for citizens since January, 2022;

- creation of a single regulator of the markets for electricity, gas, oil and oil products;

- $\quad$ integration in the field of customs policy;

- harmonization of macroeconomic policies;

- common principles of banking and financial supervision (while maintaining the central banks of the parties);

- $\quad$ integration of payment systems;

- $\quad$ single investment protection regime;

- $\quad$ mutual unified access to public procurement;

- unified system of accounting for property and the unification of economic legislation (i.e. civil codes);

- $\quad$ common principles of "special economic measures" (i.e. sanctions policy);

- industry regulation: along with the fuel and energy complex, it is proposed to harmonize (introduce a single set of regulation standards) industrial policy, state regulation regime for agricultural markets, trade, transport and communications, antitrust policy and consumer protection regime.

The Belarusian side adheres to a principled position: Minsk will sign the "roadmaps" only if the national interests of Belarus are respected. This means that the signing of the 
REVISTA DE LA UNIVERSIDAD DEL ZULIA. $3^{a}$ época. Año 11 N³1, 2020

Vladimir M. Kozmenko et al/// Russia-Belarus integration interaction ...195-222

DOI: http://dx.doi.org/10.46925//rdluz.31.14

Program should be linked to gas and oil agreements, removal by Moscow of barriers to access of Belarusian goods to the Russian market and creation of equal conditions for national producers, including through subsidies.

However, the document does not contain specific agreements on the fate of the "single" budget of the Union State. Considering that the Russian economy is almost 30 times larger than the Belarusian one, a number of experts draw attention to the risks of Belarus losing its economic sovereignty.

Given the existing "oil" problems, the Belarusian side insists on equal prices for the gas supplied with the constituent entities of Russia, marking this as one of the goals of its integration prospects. Minsk believes that these preferences are received not just like that, but as a part of a comprehensive deal with Moscow, where the Belarusian side regularly fulfills its part of the obligations. In particular, Belarus retains Russian military facilities on its territory, provides, if necessary, access to its military infrastructure, participates in the integrated air defense system and retains membership in CSTO.

The publication of information about the program caused a wide response in Belarus. The Belarusian authorities emphasized that the document provides for deepening only economic integration, not covering political issues. This position was also emphasized by the president of Belarus in September, 2019. According to some experts, the program of action will still be revised, taking into account the wary perception in the Belarusian society. They believe that even if it is signed, real steps to deepen economic integration will not necessarily be implemented. Indeed, earlier two states declared many initiatives to promote integration that remained unfulfilled. However, now the situation has fundamentally changed, since Moscow is really interested in the transition of the Union State from the field of political rhetoric to the practical plane.

The process of approving the program, and in fact, political bargaining on the conditions for the supply of Russian energy resources to Belarus, is undergoing serious difficulties. Each of the parties is trying to defend its national interests. After negotiations at the highest level in December, 2019 and January, 2020 in Sochi and Saint Petersburg, the parties failed to agree on fundamental issues and sign the "Program of Action of Russia and Belarus for the implementation of the provisions of the treaty establishing USA". 
REVISTA DE LA UNIVERSIDAD DEL ZULIA. $3^{a}$ época. Año 11 N³1, 2020

Vladimir M. Kozmenko et al/// Russia-Belarus integration interaction ...195-222

DOI: http://dx.doi.org/10.46925//rdluz.31.14

Belarus once again rejected the Russian proposals for "deep integration" within the Union State and continues to insist on the provision of "compensation" for the tax maneuver in the oil and gas sector. The only "success" of Minsk was the statement of Moscow on the allocation of a tranche under the credit program of the Eurasian Fund for Stabilization and Development (200 million dollars) and an interstate loan to refinance Belarus' obligations to Russia (600 million dollars). These agreements were reached in September, 2018, however, Belarus did not receive this amount in 2019.

Negotiations on "in-depth integration" showed that Russia and Belarus have a completely different perception of the roadmaps and the program of action. For Minsk, this is a tool with which we can create the so-called single markets, a single space for the movement of capital, goods and labor. For Russia, "deep integration" is a way to keep Belarus in the orbit of its geopolitical influence. As the head of the Belarusian Center for Strategic Studies A. Sivitsky notes: "Kremlin strategists fear that in the medium term (5-10 years) Minsk may withdraw from Russia's geopolitical orbit as a result of overcoming international isolation, normalizing relations with the West and deepening strategic partnership with China. Relations are influenced by domestic political trends in the republic: possible transit of power, arrival of a new generation of elites and objective reduction in trade and economic ties, primarily due to stagnation in the Russian economy and the crisis of Eurasian integration processes" (Sivitsky, 2020).

In order to "force integration", Russia stopped supplying oil to Belarus on January l, 2020 due to the fact that the Belarusian side did not agree to buy oil by 10 dollars per ton. Moreover, the supply of Russian oil on market conditions implies an increase in its cost for Belarusian refineries by 20 dollars per ton (price increases due to tax maneuver in Russia, excise taxes and export duties).

At the same time, Russia is not going to bring the situation to a crisis and allowed to supply oil to Belarus to companies belonging to the Russian oligarch M. Gutseriev (in January, 2020, it was planned to deliver in the amount of $600000-750000$ tons of oil, which would provide a partial load of Belarusian refineries). However, these volumes are not enough to fully satisfy domestic needs and export oil products. At the same time, export duties on crude oil produced in Belarus ceased to come into its budget. 
REVISTA DE LA UNIVERSIDAD DEL ZULIA. $3^{a}$ época. Año 11 N³1, 2020

Vladimir M. Kozmenko et al/// Russia-Belarus integration interaction ...195-222

DOI: http://dx.doi.org/10.46925//rdluz.31.14

In this regard, Minsk is looking for alternative suppliers of hydrocarbons. In early January, 2020, first deputy prime minister of Belarus D. Krutoy said that Belarus had sent commercial offers on the purchase of oil to Azerbaijan, Kazakhstan, Poland, Ukraine and Baltic countries. At the same time, Minsk increased the oil transit tax. According to the decree of the president of Belarus, the environmental tax rate will be 0.17 dollars for the transfer of 1 ton of oil (or oil products) per $100 \mathrm{~km}$, and income tax is set at 50\%.

At the same time, the Russian position on Belarus's compensation issue is that they can only be paid if a unified Tax Code is created, which will allow for a similar maneuver in relation to the prices of oil supplied to Belarus. According to the deputy prime minister and ambassador of Belarus to Russia V. Semashko, the issues of unification of taxation will be resolved during 2020-2021 and will come into effect on January l, 2022.

The current situation in Russia-Belarus negotiations suggests that the future fate of the economic integration of them will depend on a compromise on the terms of oil and gas supplies from Russia to Belarus.

While there is no compromise, the Belarusian ruling elite is trying to pursue a multipronged policy on this issue. The visit of American secretary of state M. Pompeo in February, 2020 to Belarus and his statements on the readiness to "provide Minsk with oil at competitive prices" can be used by the Belarusian side as an argument in political bargaining with Moscow. At the same time, A. Lukashenko is not interested in the first step, since Minsk is much more profitable for USA and the EU to propose a deal. Therefore, it is important for the Belarusian leader to maintain interest in the pro-Western direction in the hope that the West will offer A. Lukashenko significant financial assistance for distance from Russia.

If the Program of Action of Belarus and Russia is adopted and implemented at least partially, it will lead in any case to a transition to a model of multi-speed integration within the framework of EAEU. The consequences for the Union are far from ambiguous, as the experience of the EU shows. The adoption in 2017 of the Europe at different speeds model (differentiated cooperation) was aimed at deepening integration. This program provided that a number of countries that are ready to further deepen integration should advance faster than other EU members. But now, experts believe that this approach has led to a split between the west and east of the EU, contributing to the disintegration of this integration association. 
REVISTA DE LA UNIVERSIDAD DEL ZULIA. $3^{a}$ época. Año 11 N 31, 2020

Vladimir M. Kozmenko et al/// Russia-Belarus integration interaction ...195-222

DOI: http://dx.doi.org/10.46925//rdluz.31.14

At the current stage, EAEU countries are at the stage of development and launch of the strategic directions for the development of economic integration until 2025, and the factor of Russia-Belarus relations will continue to exert significant pressure on the course of integration processes within EAEU.

\section{Results and Discussion}

The methodology used and the source base allowed us to draw a number of results.

It is revealed that in the Union State of Russia and Belarus and the CIS countries, integration policy is currently moving into the category of strategic development tasks and should be taken into account as an indicator of the conditions for the development and growth of political, economic and socio-cultural governance structures. This is the essence of the political and socio-ecological self-identification of the Eurasian space.

It is proved that an important and necessary condition for the implementation of the integration development strategy should be recognized as expanding the spectrum and role of national and supranational governance structures, and among the likely directions of its development is the use of mutually beneficial mechanisms for combining the interests of these two countries within the Union State.

Military-technical cooperation is an important element of the integration of RussianBelarusian cooperation within the framework of the Union State, as it contributes to strengthen the security of the two countries.

The integration policy during the construction of the Union State should determine the activities of the institutional structures of Russia and Belarus to solve the most significant problems, both due to the financial resources of each country and through the use of integration-oriented tools of supranational governance.

There are the following tasks for the integration implementation:

- determination of the political and socio-economic reasons and prerequisites for the development of the processes of the formation of the Union State of Russia and Belarus; - $\quad$ assessment of the main conceptual approaches to the study of integration processes;

- $\quad$ considering the main problems of interaction between Russia and Belarus in the framework of the Union State; 
REVISTA DE LA UNIVERSIDAD DEL ZULIA. $3^{a}$ época. Año 11 N³1, 2020

Vladimir M. Kozmenko et al/// Russia-Belarus integration interaction ...195-222

DOI: http://dx.doi.org/10.46925//rdluz.31.14

- $\quad$ conduction of a comparative analysis of the system of relations between Russia and Belarus in the context of the concept of integration development in the post-Soviet states.

- identification and analysis of the priorities and main directions of RussianBelarusian military-technical cooperation.

- $\quad$ Political methods for solving integration problems should be based, first of all, on the analysis of key factors of integration processes in the post-Soviet states and should be aimed at reorienting the collective management system.

There is a need to develop interregional and international cooperation in the development and implementation of regional and multilateral agreements within the framework of a single Union State of Russia and Belarus.

The formation of the basic political and sociocultural principles of integration policy within the framework of the Union State of Russia and Belarus requires a comprehensive consideration of the current economic conditions caused by the global economic crisis.

During the construction of the Union State of Russia and Belarus, it was formed the understanding of the need to transform the existing administrative management systems at the supranational level.

The regulatory role of the Union State of Russia and Belarus should be considered as a necessary condition and a constructive basis for the functioning of EAEU.

\section{Conclusion}

Belarus found itself in a difficult transit position on the path to deepening integration. Russian experts and politicians note the negative consequences for the Belarusian economy, in the situation of abandoning the further course to deepen integration, including a drop in living standards, mass migration of the most skilled and able-bodied workers from the country. From the Russian point of view, only further integration, single tax, budget policy and transition to a single currency (Russian ruble) will make it possible to obtain cheap energy, maintain and improve the living standards of the people of Belarus. In the option of maintaining the status quo, according to expert forecasts, the value of Belarus as an ally for Russia will decrease. 
REVISTA DE LA UNIVERSIDAD DEL ZULIA. $3^{a}$ época. Año 11 N³1, 2020

Vladimir M. Kozmenko et al/// Russia-Belarus integration interaction ...195-222

DOI: http://dx.doi.org/10.46925//rdluz.31.14

In this regard, Belarus is trying to diversify its foreign policy and trade and economic ties. The following actions of the Belarusian side are forecasted in the foreseeable future:

1. The internal agenda will focus on the upcoming presidential election. A. Lukashenko will hold an election campaign in the short term, while the favorable political situation persists and the Belarusian economy has a certain margin of safety. In 2020 - 2021, the dominance of the power line and socially oriented populist economic policy will continue.

2. The announced political reforms involving the redistribution of powers between the branches of government and constitutional amendments, according to most experts, will have "facial" nature. At the same time, Minsk expects the West to reduce criticism for violating human rights and freedoms. At the same time, A. Lukashenko will try to use protests against the integration of Belarus with Russia in the negotiation process with Moscow.

3. Minsk is firmly committed to preserving its strategic autonomy, refusing to deploy Russian military infrastructure on its territory, and has consistently upheld equality with the Russian side when making decisions in the military-political sphere. As a result of this policy, the military-political mechanisms of the Union State, including URADS, cannot be used against third countries, and all military capabilities of Belarus (including in the regional grouping of troops) are under the control of Belarusian officials.

4. Belarus is preparing for serious economic trials. The authorities have taken a number of measures to diversify the economy. The reform unit of the government has been strengthened, an action plan has been developed to stabilize the economy in the event of a decrease in budget revenues.

5. In general, Russia-Belarus relations will be characterized by a periodic aggravation of relations and then friendly reconciliation. At the same time, both parties will continue to advance their interests in the course of negotiations, summits and regional forums, as well as putting forward mutually acceptable initiatives. At the official level, Moscow and Minsk will not publicly reject the idea of deepened integration, both within the Union State and EAEU.

In any case, the deepening economic integration of Russia and Belarus cannot but affect the general character of the functioning of EAEU. In addition to the emergence of new 
REVISTA DE LA UNIVERSIDAD DEL ZULIA. $3^{a}$ época. Año 11 N³1, 2020

Vladimir M. Kozmenko et al/// Russia-Belarus integration interaction ...195-222

DOI: http://dx.doi.org/10.46925//rdluz.31.14

trade and economic imbalances, the emergence of new triggers is likely, such as the introduction of a single settlement currency (ruble), which will entail the need to create a single emission center, unified budget and tax policy. In this case, the emergence of a new hotbed of tension in relations between Russia and Belarus with the collective West becomes almost inevitable. One of the negative consequences of this will be the further strengthening of the combat potential of NATO at the western borders of EAEU, as well as the political and informational pressure of the West against EAEU. It will negatively affect the dynamics of the development of Eurasian integration processes.

At the same time, it is impossible to consider the economic integration of these two union states exclusively through the prism of risks and threats. The process of combining the economic potentials of them brings benefits to other partners in EAEU. So the scientific and expert community of the Union countries, with the assistance of the Eurasian Economic Commission, needs to comprehensively assess the prospects and weaknesses of interaction among themselves in a new format.

From this point of view, a kind of "sorting" of various integration projects by competency zones takes place in the post-Soviet states: CIS as a basic universal Organization, CSTO as a military-technical one and EAEU as economic projects. SG acts as a multidimensional organization, but unlike CIS, it is a high-level integration structure (Grebenichenko \& Toktamysov, 2011). In modern conditions, the aggravation of the international situation, the strengthening of the sanction pressure of Western countries against Russia, the importance of the Union State as a universal model of integration in the post-Soviet states is growing.

\section{References}

Afonina, V. N. (2007). Single economic space of Russia, Ukraine, Belarus and Kazakhstan: virtual model and a likely prospect. Problems of the modern economy, 1(21), 51-54.

Akbergenov, I. A. (2009). Development of economic relations of the Russian Federation and the Republic of Kazakhstan in the 1990s: abstract of the dissertation of PhD in Historical Sciences. Moscow: RUDN University.

Akbergenov, I. A., Vasiliev, M. V., \& Grebenichenko, S. F. (2005). Globalization and new tasks of foreign policy // International relations at the turn of the XX-XXI centuries. Materials of the First Interuniversity Scientific and Practical Conference. Moscow: RUDN University. 
REVISTA DE LA UNIVERSIDAD DEL ZULIA. $3^{a}$ época. Año 11 N 31, 2020

Vladimir M. Kozmenko et al/// Russia-Belarus integration interaction ...195-222

DOI: http://dx.doi.org/10.46925//rdluz.31.14

Alpysbaeva, S. N., Kenzhebulat, M. K., Akmoldina, B. N., Beisengazin, K. S., \& Tautenov, E. I. (2018). Impact of the Russian economy on macroeconomic indicators of Kazakhstan. Greater Eurasia: development, security, cooperation, Yearbook of INION RAS, 1(1), 16-19.

Arbatov, A. A. (2004a). European Russia: heresy, utopia, project? Moscow: Space 2000.

Arbatov, A. A. (2004b). Russia, Europe and the USA: a virtual triangle. Moscow: Committee "Russia in a United Europe".

Avakyan, S. A. (2001). Agreement between the Republic of Belarus and the Russian Federation on the creation of the Union State: constitutional and legal aspect. Bulletin of Moscow State University, series 11: Law, 1 .

Bogaturov, A. D., Kosolapov, N. A., \& Khrustalev, M. A. (2002). Essays on the theory and political analysis of international relations. Moscow: NOFMO.

Chufrin, G. (2020). International Organizations of Economic Cooperation in the Post-Soviet Space. Problems of Eurasian Integration, 1.

Davydov, V. P., \& Grebenichenko, S. F. (2009a). Russia's energy resources for the peaceful reconstruction of the world? Social and humanitarian knowledge, 1, 22-38;

Davydov, V. P., \& Grebenichenko, S. F. (2009b). Will Russia make the right choice? Social and Humanitarian Knowledge, 5, 3-22.

Davydov, V. P., \& Grebenichenko, S. F. (2009c). World Crisis: “Alien” Goals and Interests of Russia. Social and humanitarian knowledge, 2, 3-26.

Delyagin, M. (2005). Loneliness of Russia: after the CIS. Russia and the Muslim world, 12, 18-27.

Dmitriev, E. I., \& Khurs, M. N. (2002). Belarus: results and lessons of the presidential election. Minsk: Institute for Social, Economic and Political Studies.

Dmitriev, O. N., \& Novikov, S. V. (2019). Economic Optimization of the Modular Structure of Complex Objects. Russian Engineering Research, 39(6), 503-506.

Drobizheva, L. M. (2003). Social problems of interethnic relations in post-Soviet Russia. Moscow: Institute of Sociology of the Russian Academy of Sciences.

Egorov V. G., \& Savina, O. V. (2012). Common cultural and civilizational basis is a factor in the reintegration of the post-Soviet community. Observer, 12(275), 42-51.

Evzerov, R. Ya. (2002). World processes and the CIS. Free Thought - XXI, 11, 28-36.

Fedosov, B. N. (2006). Integration of Russia and Belarus. World economy and international relations, 6, 4046.

Glazyev, S. Yu. (2001). On choosing a future development strategy. Free thought, 2, 4-23.

Glazyev, S. Yu. (2007). Development of the Russian economy in the context of global technological changes. Moscow: NIR. 
REVISTA DE LA UNIVERSIDAD DEL ZULIA. $3^{a}$ época. Año 11 N³1, 2020

Vladimir M. Kozmenko et al/// Russia-Belarus integration interaction ...195-222

DOI: http://dx.doi.org/10.46925//rdluz.31.14

Godin, Yu. F. (2001). Russia and Belarus on the path to unity: Problems of economic security of the Union State. Moscow: International Relations.

Golovchenko, R. (2013). "We are on the verge of the closest cooperation." Interview with Roman Golovchenko, First Deputy Chairman of the Goskomvoenprom industry, to the correspondent of the newspaper "File-RF". Retrieved at. https://vpk.gov.by/special/news/2792/

Grebenichenko, S. F. (2009). Transformation of the Commonwealth of Independent States at the beginning of the XXI century. CIS Yearbook: Problems, Search, Solutions. Moscow, 24-47.

Grebenichenko, S. F. (2011). Multivariance of integration processes in the CIS. CIS Yearbook: Problems, Search, Solutions. Moscow, 5-32.

Grebenichenko, S. F. (2012a). 20 years of the CIS: new integration acceleration. CIS Yearbook:Problems, Search, Solutions. Moscow, 5-14.

Grebenichenko, S. F. (2012b). In the wake of integration. Social and humanitarian knowledge, 1, 20-42.

Grebenichenko, S. F., \& Davydov, V. P. (2005a). Globalization, Russia's interests and the CIS crisis. Social and humanitarian knowledge, 5, 3-25.

Grebenichenko, S. F., \& Davydov, V. P. (2007). Putin's Russia. Moscow: Alvian.

Grebenichenko, S. F., \& Davydov, V. P. (2008). Energy resources and geopolitical interests of Russia. Bulletin of the Peoples' Friendship University of Russia. Series: Political Science, 4, 76-90.

Grebenichenko, S. F., \& Sagindikov, R. E. (2014). Status and prospects of economic cooperation of the Russian Federation and the Republic of Kazakhstan. Social and humanitarian knowledge, 6, 23-28.

Grebenichenko, S. F., \& Toktamysov, S. Zh. (2010) Central Asian Regional Economic Cooperation is an integration project for Greater Central Asia and the Commonwealth of Independent States. Evolution of the Commonwealth of Independent States: achievements and problems. Materials of the II All-Russian Scientific and Practical Conference. Moscow, 75-85.

Grebenichenko, S. F., \& Toktamysov, S. Zh. (2011). Central Asia and the geostrategy of Russia. Social and humanitarian knowledge, 1, 3-27.

Grebenichenko, S. F., \& Toktamysov, S. Zh. (2013a). Metamorphoses of post-Soviet integration. Social and humanitarian knowledge, 2, 3-34.

Grebenichenko, S. F., \& Toktamysov, S. Zh. (2013b). Integration Potential of the Post-Soviet Space for a Quarter Century: Problems and Prospects. Bulletin of RUDN University. Series: History of Russia, 2, 52-64.

Grebenichenko, S. F., \& Toktamysov, S. Zh. (2013c). Integration Potential of the Post-Soviet Space for a Quarter Century: Problems and Prospects. Bulletin of the RUDN University (series: Russian history), 2, $52-63$.

Grebenichenko, S.F., \& Davydov V.P. (2005b). Russian Federation, its closest and most distant neighbors at the turn of the XX-XXI centuries. Moscow: RUDN University. 
REVISTA DE LA UNIVERSIDAD DEL ZULIA. $3^{a}$ época. Año 11 N³1, 2020

Vladimir M. Kozmenko et al/// Russia-Belarus integration interaction ...195-222

DOI: http://dx.doi.org/10.46925//rdluz.31.14

Ilyin, M. V. (2004). Types and varieties of world development policies. Political science, 1, 7-21.

Imankulov, A. V. (2005). International significance of the development of the oil and gas industry of the Republic of Kazakhstan in the 90s of the XX century: abstract of the dissertation of the candidate of historical sciences. Moscow: RUDN University.

Irkhin, A. A. (2014). Reintegration of the post-Soviet space: models, conditions, forecasts. Retrieved at: https://cont.ws/@alex/63121

Kachalov, V. V. (2003). Problems of formation of the Union State of Belarus - Russia as a new form of integration. Abstract of a dissertation for the degree of Doctor of Political Science. Moscow: Institute for Social and Political Studies, RAS.

Karbalevich, V. I. (2002). Paradoxes of Russian-Belarusian integration. Modern Europe, 2(10), 83-88.

Koktysh, K. (2004). Post-Soviet transformation of Belarus. World Economy and International Relations, 1, $37-50$.

Konobeev, V. (2003). EU - Russia - Belarus. World Economy and International Relations, 5, 109-111.

Kornilovich, S. V. (2007). Conditions for the formation of an optimal currency zone within the EAEC. Problems of the moderneconomy, 1(21), 46-50.

Kozmenko, V. M. (2001). Foreign policy of Russia as a security factor. Bulletin of the Peoples' Friendship University of Russia. Series: International Relations, 1, 121-129.

Kozmenko, V. M. (2009). Commonwealth of Independent States is a new form of interethnic integration. CIS: problems, search, solutions: 2010. Moscow, RUDN University, 11-22;

Kozmenko, V. M. (2012a). Priority lines of integration of Russia and Kazakhstan in 1991-2010. Bulletin of RUDN University. Series: History of Russia, 1, 102-109.

Kozmenko, V. M. (2012b). Russia in the CIS system: forms of cooperation. CIS Yearbook: Problems, Search, Solutions. Moscow, 49-60.

Kozmenko, V. M., \& Sagindikov, R. E. (2014). Customs Union of Russia, Kazakhstan and Belarus the basis of their economic security. Bulletin of RUDN University. Series: International relationships, 4, 8794.

Legwold, R., \& Wallander, S. A. (2004). Swords and screaming. National security economy of Belarus and Ukraine. American Academy of Humanities and Sciences. Cambridge: Interdialect.

Libman, A. M., \& Kheyfets, B. A. (2011). Models of economic disintegration. Integration and disintegration. Eurasian economic integration, 2(11), 4-18

Lokosov, V. V. (2011). Union state of Belarus and Russia in the public opinion of the two countries. Minsk: Centre for System Analysis \& Strategic Research The National Academy of Sciences of Belarus.

Lublinsky, V. V. (2005). Transformation of society and social policy in Western countries: The second half of XX - beginning of XXI century: Monograph. Moscow: RUDN University, 2005. 
REVISTA DE LA UNIVERSIDAD DEL ZULIA. 3época. Año 11 N 31, 2020

Vladimir M. Kozmenko et al/// Russia-Belarus integration interaction ...195-222

DOI: http://dx.doi.org/10.46925//rdluz.31.14

Luzyanin, S. G. (2007). Vladimir Putin's Eastern policy: Russia's return to the "Big East" (2004-2008). Moscow: AST.

Mihalisko, K. (1992). Belarus Moves to Assert Its Own Military Policy. Radio Free Europe/Radio Liberty Research Report, 48.

Mihalisko, K. (1996). Belarus: Retreat to Authoritarianism. Democratic Changes and Authoritarian Reactions in Russia, Ukraine, Belarus and Moldova. Cambridge: Cambridge University Press.

Mikhaleva, N. A. (2002). Legal problems of creating the Union State of Russia and Belarus. State and law, 6, 14-21.

Moravcsik, A. (1995) Liberal Intergovemmentalism and Integration: A Rejoinder. Journal of Common Market Studies, 33(4), 611-628.

Novikov, S. V. (2019). Peculiarities of training of high-tech enterprise specialists under modern conditions. IOP Conference Series: Materials Science and Engineering, 537(4).

Olcott, M. B. (1996). Central Asia's New States: Independence, Foreign Policy and Regional Security. United States Institute of Peace Press, 72(4), 862-863.

Pankov, V. (2007). Integration and disintegration in the post-Soviet space. World of change, 3, 128-142.

Pastukhova, N. B. (2000). Union of Russia and Belarus. History, present, prospects. Moscow: Book and business.

Podlesny, P. T. (1995). Geopolitical changes in Europe, Western policy and alternatives for Russia. Reports of the Institute of Europe RAS, 18, 92.

Rapota, G. A. (2005). EAEC: Economic Attraction: Collection of Articles. Moscow: MUK SD.

Sarazhanov, A. M. (2002). Kazakh-Russian relations in the 90s of the XX century: experience, problems: abstract of the dissertation of the candidate of historical sciences. Moscow: RUDN University.

Shakleina, T. A. (2000). Belarus in the foreign policy strategy of the Russian Federation: Discussions on the union of Russia and Belarus in the Russian political and academic community: geopolitical aspect. Moscow: Moscow Public Science Foundation: Publishing Center for Scientific and Educational Programs.

Shakleina, T. A. (2010). Belarus in the foreign policy strategy of the Russian Federation. Moscow: Moscow Public Science Foundation.

Shamishev, E. D., \& Toktamysov, S. Zh. (2019). Eurasian Economic Union in the context of sanctions policy. Amazonia Investiga, 8(21), 474-482.

Shishkov, Yu. V. (2001). Integration processes at the threshold of the XXI century. Why CIS countries are not integrated. Moscow: 3 Tysyachiletie.

Shtol, V. V. (2012). Post-Soviet states: the search for self-identification and the costs of independence. Browser, 12, 29-41. 
REVISTA DE LA UNIVERSIDAD DEL ZULIA. $3^{a}$ época. Año 11 N³1, 2020

Vladimir M. Kozmenko et al/// Russia-Belarus integration interaction ...195-222

DOI: http://dx.doi.org/10.46925//rdluz.31.14

Sivitsky, A. (2020). "Union State is inscribed in the transit of Putin's power." Center for Strategic and Foreign Policy Research. Retrieved at http://csfps.by/ru/posts/20200122

Sobin, V. (2012). Military-technical cooperation between Russia and Belarus is gaining momentum. Military Review. Retrieved at http://topwar.ru/17151-voenno-tehnicheskoe-sotrudnichestvo-mezhdu-rossieyi-belorussiey-nabiraet-oboroty.html

Suzdaltsev, A. I. (2009). Formation of the Russian policy towards Belarus (2005-2008). World Economy and International Relations, 3, 64-74.

Tatarintsev, V.M. (2011). Bilateral relations of Russia with the CIS countries: monograph. Moscow: East West.

Timmerman, H. (2006). Special case of Belarus. Russia in global politics, 2(4).

Tkachev, D. Sh. (2006). Features of the functioning of institutions and social networks in the postSoviet space. Political Studies, 1, 78-91.

Tsyganok, A. D. (2009). Military-technical cooperation between Russia and Belarus. Retrieved at https://tsiganok.ru/publications/esmi/doc/475

Ushkalova, D. I. (2008). Problems and prospects of economic integration of Russia and Belarus: the dissertation of the candidate of economic sciences: 08.00.14. Moscow: Institute of Economics of the Russian Academy of Sciences.

Vinokurov, E., Dzhadraliev, M., \& Shcherbanin, Yu. (2009). EAEC International Transport Corridors: Faster, Cheaper, More. Industry review. Almaty: Eurasian Development Bank.

Vishnyakov, V. G. (2002). On the correlation of international and constitutional law (on the example of Belarus and Russia). Journal of Russian Law, 9, 11-21.

Zayko, L. F., Karbalevich, V. I., \& Abramova, O. M. (1999). National-state interests of the Republic of Belarus. Minsk: Skakun. 